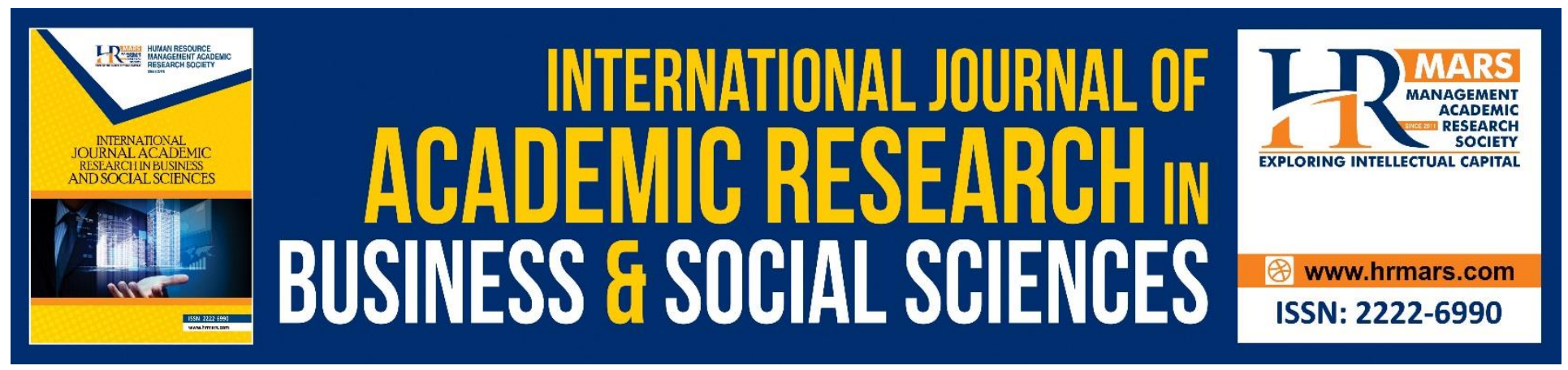

\title{
Influencers of Performance Contracting in Service Delivery: A Trend Analysis in the State Department of Water and Irrigation of Kenya
}

Mukabi K. E. Fredrick, Josephine Mwanzia, William Nyabuto

To Link this Article: http://dx.doi.org/10.6007/IJARBSS/v10-i11/8077

DOI:10.6007/IJARBSS/v10-i11/8077

Received: 02 September 2020, Revised: 28 September 2020, Accepted: 13 October 2020

Published Online: 13 November 2020

In-Text Citation: (Fredrick, Mwanzia, \& Nyabuto, 2020)

To Cite this Article: Fredrick, M. K. E., Mwanzia, J., \& Nyabuto, W. (2020). Influencers of Performance Contracting in Service Delivery: A Trend Analysis in the State Department of Water and Irrigation of Kenya . International Journal of Academic Research in Business and Social Sciences. 10(11), 193-214.

Copyright: (c) 2020 The Author(s)

Published by Human Resource Management Academic Research Society (www.hrmars.com)

This article is published under the Creative Commons Attribution (CC BY 4.0) license. Anyone may reproduce, distribute, translate and create derivative works of this article (for both commercial and non-commercial purposes), subject to full attribution to the original publication and authors. The full terms of this license may be seen

at: http://creativecommons.org/licences/by/4.0/legalcode

Vol. 10, No. 11, 2020, Pg. 193 - 214

http://hrmars.com/index.php/pages/detail/IJARBSS

JOURNAL HOMEPAGE

Full Terms \& Conditions of access and use can be found at

http://hrmars.com/index.php/pages/detail/publication-ethics 


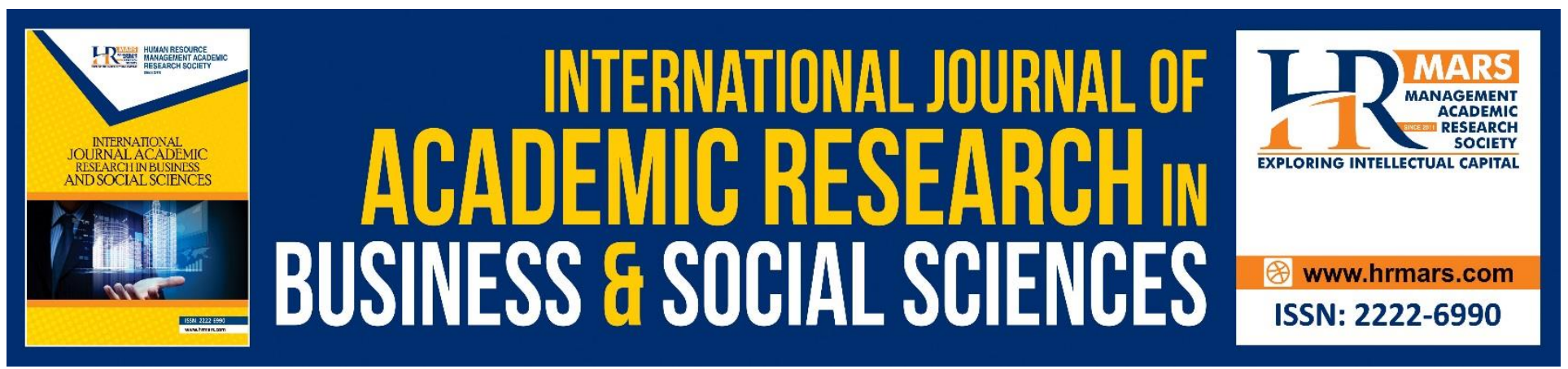

\title{
Influencers of Performance Contracting in Service Delivery: A Trend Analysis in the State Department of Water and Irrigation of Kenya
}

\author{
Mukabi K. E. Fredrick, Josephine Mwanzia, William Nyabuto
}

Deputy Director, KSG Embu, Director, Academic Affairs, KSG, Member of Faculty, KSG Embu

Email: fredrick.mukabi@ksg.ac.ke, josephine.mwanzia@ksg.ac.ke,william.nyabuto@ksg.ac.ke

\begin{abstract}
Performance Contracting (PC) is a globally accepted approach towards helping governments delivers services to its citizenry. In Kenya, performance contracting is an integral part of the performance management framework and is a tool for Government Ministries, Departments and Agencies (MDAs) used to constantly improve service delivery in line with the reforms within the Kenya Vision 2030 blueprint and a facilitator in the realization of the Big Four Pillars (manufacturing, affordable housing, healthcare and food security) of the Government. In the PC are indicators on Budget Absorption, Service Automation and Employee Satisfaction, considered proxy indicators in this paper. The objective of this study is to assess how Performance Contracting through these proxy Key Performance Indicators (KPIs) of budget absorption, service automation and employee satisfaction on service delivery, within the Ministry of Water and Irrigation. A longitudinal research design is adopted in the study. The study relies on Secondary data that was obtained from the Ministry of Water and Irrigation headquarters. Trend analysis is undertaken on the KPIs for targets and achievements for ten (10) year ranging between FY 2005/2006 to 2014/2015. In addition, correlation analysis is computed to establish whether there is a relationship between the independent and dependent variables. Tabulations, charts and graphs are used to summarize and present the findings. The analysis reveals that there is a strong positive relationship between budget absorption with a set of proxy service delivery parameters of access to water services and customer satisfaction. However the relationship between service automation and employee satisfaction with these service delivery parameters seems weak. This helps the researcher to conclude that the implementation of performance contracting based on the KPIs has nevertheless had a positive effect on service delivery in the10 years. The paper recommends the need to continue improving on budget utilization, on the need for appropriate service automation and relevant employee motivation strategies to improve service delivery.
\end{abstract}

Keywords: Performance Contracting, Key Performance Indicators, Service Automation, Budget Absorption, Customer Satisfaction. 
INTERNATIONAL JOURNAL OF ACADEMIC RESEARCH IN BUSINESS AND SOCIAL SCIENCES Vol. 10, No. 11, 2020, E-ISSN: 2222-6990 @ 2020 HRMARS

\section{Introduction}

Performance contracting in public service emerged with the adoption of the New Public Management (NPM) approach which has a theoretical basis from the Public - Choice theory. Public sector according to Trivedi refers to economic and administrative life that deals with the delivery of goods and services to the people, whether at national, regional or local levels.

In the public sector, a performance contract is an agreement between a government and public agency which establishes general goals for the agency, set targets for measuring performance and provides incentives for achieving these targets.

The use of performance contracting according to Obong'o has been acclaimed as an effective and promising means of improving the performance of the public sector service.

Globally, France is regarded as the first country to introduce PC as a performance improvement tool within the public service in the late 1960s before it was adopted in other countries such as Pakistan, Korea and later India. By 1990s, PC model had been adopted in management of public service in many countries'. The success of performance contract in these countries generated a great deal of interest in policy around the world (Miller, 2016). A large number of government and international organizations are currently implementing policies using this method to improve the performance of the public sector in their respective countries. Performance contracts represent a state of the art tool for improving public sector performance. It is now considered an essential tool for enhancing good governance and accountability for results within the public sectorii.

Within the Kenyan context a performance contract is regarded as a written agreement between government and a State Agency delivering services to the public, wherein quantifiable targets are explicitly specified for a period of one financial year (July to June) and performance measured against agreed targets.

Historically, the Government of Kenya (GoK) had tried various reforms in the public sector over the years with varying degrees of success. These efforts seemed relatively fragmented and sectoral in nature and had their varied measure of performance evaluation and success. When the need for reforms became a government agenda, a uniform way of measuring performance became a prerequisite. These public sector reforms had been primarily introduced in Kenya to reverse falling service delivery.

It is noteworthy that Performance Contracts have their origins in the perception that the Performance of the public sector has not been at par with the expectations of the public; thus the need to reverse this trend. The concept of Performance contracting was first introduced in the management of State Corporations' in 1989. In 2003 GoK directed that Results based Management (RBM) to be introduced in the entire public service. In pursuit of Performance improvement within the public sector, The Government of Kenya then introduced Performance Contracts in order to establish the basis for ensuring that efficient and effective services are delivered to Kenyans in line with the provisions of the Constitution and by requiring MDAs to adopt human rights approach to service delivery.

Performance Contracts were first introduced on 1st October 2004, in (sixteen) 16 largely commercial State corporations. In 2005/2006, all the then 35 Government ministries/departments, 116 state Corporations and five pilots local authorities signed Performance Contracts. PCs are currently modeled on and achieved through the following broad parameters namely: Finance Stewardship and Fiscal Discipline; Implementation of Presidential Directives; Core Mandate; and Cross cutting issues. 
INTERNATIONAL JOURNAL OF ACADEMIC RESEARCH IN BUSINESS AND SOCIAL SCIENCES Vol. 10, No. 11, 2020, E-ISSN: 2222-6990 @ 2020 HRMARS

The ultimate objective of Performance contracting is to ensure that Performance is measured using international best practices and that Performance targets are grown to the extent of placing the country at the peak of global competitiveness. The Ministry's Performance Contract is cascaded to all departments, sections, levels and cadres of employees and grass-root institutions for the purpose of complete integration of the process. The integration includes linking the Performance Contract with resource allocations, the Performance Appraisal System (PAS) (GoK, 2014).

The Ministry of Water and Irrigation is mandated to improve access to clean and safe water through construction of Water projects both in urban and rural areas. The Ministry ensures that annual Performance targets are aligned to Medium Term Plans (MTP) of Kenya Vision 2030, strategic plans and approved budgets. It has been implementing Performance contract from 2005/06 financial year which is geared towards universal access to clean and safe Water as envisioned in the Social Pillar of Kenya Vision 2030. However there has been low access to clean and safe water in comparison to the then MDG target of 77\% access to clean water by the year 2015 .

In introducing Performance Contracts in 2003 the Government purposed to improve public service delivery based on the performance management framework. The PC is widely perceived as an effective way to providing quality goods and services in the public sector within the existing budgetary constraints (Kariuki, 2011). The PC has been hugely celebrated and is associated with improvements in service delivery in the public sector in Kenya according to Muthaura, (2010).

However, there is a general view that the PC may not have brought any meaningful change in the quality of service delivery within the public sector with various researches being carried out to investigate this. None so far has focused on the KPIs identified and moreso in the Ministry of Water and Irrigation. According to a study on the effect of performance contracting on organizational performance in the Ministry of Education in Kenyaiii performance contracting was found to have had a great effect on the improvement of service quality. A similar study conducted by Kobia and Mohammed found that performance contracting had induced the public service to become more oriented towards customers, markets and performance, without putting the provision of essential public services into jeopardy. According to the findings, the introduction of contracts and management by results had been used to improve the performance as it emphasizes better the human resource management.

Despite all these studies, there exists limited research that has been conducted in the Ministry of Water and Irrigation focusing on the KPIs under study to determine the effectiveness of Performance contracting in improving to service delivery of the water sub-sector. This study intended to find out whether introduction of Performance contracting had improved service delivery in this Ministry since it is a key sector in the Social Pillar in the realization of Kenya Vision 2030 targets.

The General Objective of this study is to assess the Effect of Performance Contracting on service delivery. Specifically, the study aims at

- Assessing how budget absorption in the PC influences service delivery;

- Determining how service automation in the PC affects service delivery; and

- Assessing how employee satisfaction with the PC influences service delivery.

The findings of the research paper are expected to assist the water sector in implementation of Performance Contracting in respect to the identified KPIs and other indicators to improve service delivery and policy formulation to fast track universal access to clean and safe Water. In addition, these research findings can be used to form basis for future research on Performance contracting. 
INTERNATIONAL JOURNAL OF ACADEMIC RESEARCH IN BUSINESS AND SOCIAL SCIENCES Vol. 10, No. 11, 2020, E-ISSN: 2222-6990 @ 2020 HRMARS

The study covered the Ministry of Water and Irrigation Performance from the Financial Year (FY) 2005/06 to 2014/15 FY. The Ministry is situated at Maji House, Ngong Road in Nairobi, Kenya. It comprises of two State departments namely: State Department of National Water services and State Department of Irrigation.

\section{Review of Literature \\ Performance Contracting}

The PCs were introduced as a management tool for measuring Performance against negotiated Performance targetsiv. The use of Performance Contract has been acclaimed as an effective and promising means of improving the Performance of public sector as well as a tool for enhancing good governance and accountability in service delivery. The key objectives for introducing Performance Contracting in the public service are: To promote responsiveness; improve efficiency by focusing resources on the attainment of key National Policy priorities of Government; institutionary of Performance oriented culture in the public service; to measure and evaluate Performance; linking rewards to measurable Performance; competency development; to oversee the governance systems in public organizations; to allow for bench marking with the best practices; learning and innovation; stakeholder involvement and promote accountabilityv.

The main purpose of the Performance contracting according to Armstrong and Baron, 2004 is to ensure delivery of quality service to the public in a transparent manner for the survival of the organization. Since public services are collectively rendered through Government Ministries, departments and collective units comprising of employees hence they have to be managed effectively, efficiently and economically. It is on this basis that the collective units are expected to perform at a particular level to measure the type of service delivered against the recipients' expectations. The level of Performance by collective units will ultimately represent the level of service delivery.

\section{Budget Absorption}

The Ministry is funded by National Government, Development Partners (DPs) and funds which are internally generated. The financial out-turn on budget absorption in the study will focuses on revised budgets and the actual disbursed funds based on the voted budgetary provisions. It covers only funds from national Government, Development partners and internally generated funds. The disbursed funds at the national level are a good measure of actual expenditure during the year since all disbursed funds are spent during the financial year by the Ministry and its parastatals. The funds from Development Partners are disbursed through the National Treasury (revenue) or through direct payments to projects as Appropriation-in Aid (A-in-A). Experience in the past has shown the development partners normally prefer to channel their funds through direct payment to Water projects because it is less bureaucratic and more efficient.

Budget absorption rate is the amount of money the Ministry actually manages to spend every year during the study period. Since the economic growth of the country is often tied to public and private expenditures, failure to spend budgeted money directly affects the rate at which the economy expands. Absorption of budget funds in the Ministry may be affected by a wide range of factors, including; bureaucracies getting approvals, complex, cumbersome and sophisticated procurement procedures, endless court battles initiated by aggrieved parties in Government tendering processes, late disbursements of funds to ministries, departments and agencies 
INTERNATIONAL JOURNAL OF ACADEMIC RESEARCH IN BUSINESS AND SOCIAL SCIENCES Vol. 10, No. 11, 2020, E-ISSN: 2222-6990 @ 2020 HRMARS

(MDAs),stringent and often stifling conditions of donor funds, weak monitoring systems, leakages coupled with misuse of public funds by those implementing public projects.

\section{Service Automation}

Automation is the employment of control systems and information technologies to reduce the need for human work in the production of goods and services. It plays an increasingly significant role in the world economy. Automation has had a notable impact in a wide range of industries and organizations $^{\mathrm{vi}}$. The emergence of Information and Communication Technology has provided means for faster and better communication, efficient storage, retrieval and processing of data and exchange and expenditure of information to its users, be they individuals, groups, businesses, organizations or Governments. Application of ICT in the Ministries is aimed at changing the way Ministries conduct their operations. In order to attain this vision, it is important that the Government stocks the necessary ICT skills set for the implementation and maintenance of the e-Government strategy.

At the Ministry of Water and Irrigation, automating functions is one of the ways of improving operating performance and enhancing effective and efficient service delivery. Technology and technological innovation often have a major influence on business organizations. Technological innovation in products and services can produce tremendous benefits for organizations which can yield a competitive advantage by often helping to increase their market share and generate substantial profits. With Automation as one of the indicators of the Performance contract the Government aims to greatly cut its back office operational cost, improve efficiency in its operation and subsequently provide quality service to the public.

Service delivery is a continuous, cyclic process for developing and delivering user focused services. Quality service delivery involves a comparison of expectations with Performance. Service quality is a measure of how well a delivered service matches the customer's expectations (Lewis and Booms, 1983). Quality focus is so as to meet customer needs while remaining economically competitive at the same time. It is notable that Government Ministries have automated some of their core operations such as financial management and procurement processes and are now able to deliver information and services more efficiently and accurately. Wide Area Networks (WAN), Local Area Network (LAN), Internet websites, and Mobile service platforms and Computing, are being used to transform Government operations through these ministries hence improving service delivery.

The Ministry of Water and Irrigation has been taking a lead role in the implementation of eGovernment initiatives which have since been institutionalized and operationalized. Operations in the Government Common Core Network (GCCN) such as IFMIS operations, e-Procurement, on line registration of Water contractors and professionals, Maji Voice that enables the customers to easily and conveniently reach their Water companies (Otieno, 2015).

\section{Employee Satisfaction}

This is considered as the combination of affective reactions to the differential perceptions of what he/she wants to receive compared with what he/she actually receives (Cranny, Smith, \& Stone, 1992). Because of this, the organizations are expected to try providing the employee expectations in order to achieve the employee satisfaction. Subsequently, the emotional state of the employees may also affect their satisfaction levels. This compels the managers to create and sustain the desired working environments in the organizations. Organ and Ryan (1995), opine that employee satisfaction is one of the basics of organizational citizenship behavior. The well-satisfied employees will always 
INTERNATIONAL JOURNAL OF ACADEMIC RESEARCH IN BUSINESS AND SOCIAL SCIENCES Vol. 10, No. 11, 2020, E-ISSN: 2222-6990 @ 2020 HRMARS

work more willingly and this contributes to the efficiency and effectiveness of their respective organizations.

Employee satisfaction is a key performance measures in the performance contract and a critical performance management tool which is carried out periodically to establish the level of satisfaction and identify the areas of improvement. It is measured under internal customer satisfaction. Piriyathanalai and Muenjohn, (2012) in their study on the link between employee satisfaction and quality of service, established that the employee satisfaction toward work related factors had significance relationships with service quality, service cost and service delivery. Research on the impact of employee's job satisfaction on organizational performance by Latif, Ahamad et al, (2013) found that there existed a positive correlation between employee satisfaction and organization performance.

\section{Service Delivery and Access to Clean Water}

The implementation of sector reforms has been ongoing in the Ministry of Water and Irrigation since the enactment of the Water Act 2002. From these, the new legal and institutional framework seeks to improve sector efficiency and overall performance. The sector reform also aimed at significantly contributing to the realization of the then Millennium Development Goals. Implementation of the reforms has continued to receive impetus from developments partners at both national and international level. These include the Vision 2030, the Human Rights Declaration to Water and Sanitation that seeks to give equal right to access for all and Constitution of Kenya 2010 (Otieno et al., 2015). The Ministry has a constitutional obligation to ensure every person in Kenya has the right to adequate, clean water and to reasonable standards of sanitation as stipulated in Article 43 of the Constitution of Kenya, 2010.

This implementation of the sector reforms have faced hurdles to overcome during their implementation. Key among these challenges faced during the reform process being the rapid increase in population that continually places pressure for increased water infrastructure development for effective services provision. With this, there is therefore need to put in place plans to achieve realization of universal access to clean water as enshrined in the Constitution of Kenya 2010 and Vision 2030.

The absolute realization of universal access to Water appears to be a daunting task to the Ministry that must be performed considering that about 17.6 million Kenyans are using water whose sources are considered unsafe; hence the task of providing safe water is much heavier at independence when there were only about 6 million Kenyans.

The Kenyan Public sector reforms have been focusing on the improvement of service delivery and there is therefore need to undertake research to check on progressive realization on access to safe and clean water as a means to improved service delivery. The study will be useful in policy formulation since it will inform the key areas that need to be fast tracked to improve service delivery through enhancing the access to safe and clean water.

\section{Service delivery and Customer Satisfaction}

Customer Satisfaction refers to the utility derived by the customers of a product or service as attested by the independent opinion of the consumer of that product or service. The Business Dictionary defines Customer Satisfaction is the degree of satisfaction provided by the goods or services of a company as measured by the number of repeat customers. It may also be defined as a 
INTERNATIONAL JOURNAL OF ACADEMIC RESEARCH IN BUSINESS AND SOCIAL SCIENCES Vol. 10, No. 11, 2020, E-ISSN: 2222-6990 @ 2020 HRMARS

post consumption evaluative judgment concerning a specific product or service (Gundersen et al, 1996). It is the result of an evaluative process that contrasts pre-purchase expectations with perceptions of Performance during and after the consumption experience (Oliver, 1980).

Customer satisfaction is becoming an important part of the culture of many organizations (Ladewig, 1997). It provides for better understanding of services provided by an organization from the customers' perspective and also provides for better understanding of expectations of customers and the extent to which an organization is satisfying the needs and wants of its customers. Customer satisfaction also serves as a link between the customers and a Performance reward system, thus providing rewards for desired outcomes and identifying consequences for undesired outcomes. Customer satisfaction is an indicator of the quality of the services provided and is critical for evaluation of the effectiveness of the organization (Gundersen et al, 1996).

Since the introduction of Performance Contracting in 2004, The Ministry of Water and Irrigation has since acknowledged that citizens require improvements in quality of services for them to be satisfied. So as to enhance customer satisfaction, the Ministry has been making effort to measure and improve the approaches to service delivery through designing and redesigning customer interaction processes and implementation of programmes considering that citizens expect quality services and value for their money (Otieno et al, 2015). Therefore it is essential to evaluate the content of the programmes and be in sync with new developments in the field to sustain their quality of the provision of services to the public. Customer satisfaction surveys are useful as they predict the success of an organization since they directly interrogate the critical success factors of service delivery when conducted accurately. They deliver incisive and useful information and provide ways to gain a competitive edge in business. The ultimate goal of service provider is to deliver a service of high quality and to increase customer satisfaction (Spreng et al, 1996).

\section{The New Public Management Theory}

Performance contracting in the public service emerged with adoption of the New Public Management (NPM) theory. This is a set of operating principles captured by Osborne and Gabler, (1991) as practical solutions to the operational problems confronting governments, Miller and Dunn (2015). Primarily, government organizations were seen as undemocratic, unresponsive, inefficient and failing in most measures of an effective organization. Osborne and Gaebler (1991) identified ten (10) principles that represent an operational definition NPM. These are: responsibility of governments to steer delivery of public service; governments need to be community owned; competition is good in enhancing service delivery; governments should be driven by missions; governments should be judged on the results they generate; the perception of citizens and consumers of public goods as customers; the desirability of orienting public agencies toward preventing rather than curing public problems; allowing people to participate in decision-making and leveraging on market forces and utilizing market-based strategies in delivery of public goods. According to Miller and Dunn (2015), all the features of the NPM principles have been incorporated in performance contracting system to fulfill the obligations of governments to the public.

Other scholars have attempted to underscore the benefits the PC in service provision. In their study on performance contracting in Finnish public organizations, Uusikyla and Virtanen (1999) found that some of the benefits that were associated with its introduction were better coordination between state agencies themselves and between them and the parent ministry as well as better linkage with planning and budgeting process. Other studies in Mauritius by Chittoo (2009) found that 
there was a very complex communication system in the public service with each ministry jealously guarding its sphere of influence. This therefore suggested that performance contracting in Africa may not have had meaningful impact on internal communication between institutions. The enhanced creativity through PC and strong focus on results introduced at the District and sector and sub-sector levels had translated into significant national development outcomes according to the African Development Bank ${ }^{\text {vii }}$.

The works of Letangule and Letting, (2012) in their study on the effects of Performance Contract on Organization Performance; A case of the Ministry of Education in Kenya established that performance contracting enhances service quality through improved service quality, efficiency, and consistency and employee creativity at the ministry of education to a great extent. Specifically, the results showed that taking all other independent variables at zero, a unit increase in service quality will lead to a 0.188 increase in performance (Otieno et al, 2015).

The contributions of Albeity (2012) in his study on the effects of performance contracting on service delivery at the Mombasa Municipal Council, established that performance contracting improves service delivery, improves employee accountability and enhanced team spirit due to its ability to motivate employees to work. Using both primary and secondary data with the case study research design, he conducted in-depth interviews with 12 top management team of the council, who were involved in the performance contracting. It focused on financial constraints, shortage of staff, political interference and negative attitude by stake holders, lack of adequate facilities and technical staff as the major sources of challenge to service delivery to the people of Mombasa municipality. After analysis, the results showed that $90 \%$ of employees were able to deliver as per their service targets.

The contributions of Nganyi et alviii in their study on the effectiveness of Performance Contracting in Service Delivery in Public Universities in Kenya; A case of Masinde Muliro University of Science and Technology, established that there had been significant improvement in service delivery even though the impact was yet to be fully felt. With the parameters Reduced Customer Complaints; Optimal Expenditure of Resources; Increase in Revenue Collection; Cost containment; Reduced Bureaucracy; Improved Governance; Improved Service Delivery and Reduced Dependence on the Exchequer, the study results showed that in overall, $82 \%$ of the respondents believed that Performance contracting had improved service delivery in the university.

The input of Sifuna, (2012) who undertook a study on Perceived Effect of Performance Contracting on Service delivery at Jomo Kenyatta University of Agriculture and Technology (JKUAT) revealed that since the performance contract was introduced, there had been faster response to customer enquiries and problems, customers enjoy greater convenience and control, staffs are able to offer better services and customer queries are handled faster. However, established that there was no reduction in customer complaints, delays in services have not reduced, there were no faster services, there was no increase in customer compliments and customer satisfaction index has not improved.

These studies demonstrate that performance contracting has improved service delivery. However a comprehensive investigation using key predictors of budget absorption, employee satisfaction and automation and how they influence service provision has not been undertaken. The focus seems to have been on the process implementation in most of the studies undertaken other than focusing on performance indicators. 
INTERNATIONAL JOURNAL OF ACADEMIC RESEARCH IN BUSINESS AND SOCIAL SCIENCES Vol. 10, No. 11, 2020, E-ISSN: 2222-6990 @ 2020 HRMARS

\section{Methodology}

The study employs trend analysis based on the longitudinal research design which was used in this study to assess the effectiveness of performance contracts in the Ministry of Water and Irrigation. Longitudinal design according to Kothari (2011) permits the measurement of differences or change in a variable from one period to another. The Ministry of Water and Irrigation has been implementing Performance Contracting for the last ten years since 2005/06 to 2014/15, thus longitudinal design would enable description of patterns of variable changes over time. This is the data that the researcher was able to access because subsequent years' data is not yet analyzed. Desk review was undertaken through the collection of secondary data from published government data, which was subjected through quantitative data analysis. Based on this research design, there was no target population.

The Key Performance Indicators (KPIs) selected for the study are Budget Absorption, Services Automation and Employee satisfaction. These independent variables/performance indicators are selected out of other PC indicators based on their direct contribution to service delivery. Baseline data of FY 2005/06 was used to determine the trends and variations up to FY 2014/15. The independent variables are correlated with the proxies of service delivery that is access to clean water and customer satisfaction to establish their relationship.

The sourcing of data forms an important component of this study. The researcher observes that since inception, the Government has been implementing Performance Contracting in Ministries, Departments and Agencies (MDAs) and hence the Ministry of Water and Irrigation was purposefully selected as a representative of the Kenyan Public Service sector. The study employs secondary data which is obtained from the Ministry of Water and Irrigation covering the FY period between 2004/05 to 2014/15. The data includes Annual PCs, $4^{\text {th }}$ quarter and Annual Performance Contract progress reports, Water Sector review reports, Strategic Plan 2008-2012 and 2013-2017 and Performance Expenditure Reviews.

The data collection for this research is based on secondary approaches to the process. Oso and Onen (2011), define data is anything given or admitted as a fact on which a research inference will be based. Cooper and Schindler (2011) and Mugenda \& Mugenda (2012) define data collection instruments as the tools and procedures used in the measurement of variables in research.

In this paper, secondary data is collected from documents for the Ministry on the basis of a developed template extracted from the research questions. Secondary data collection method is used since the required data covered a period of ten years and is easily available and retrievable from actual performance reports.

On analysis, Bell (1993), proffers that when making the results known to a variety of readers, simple descriptive statistics such as percentage have a considerable advantage over more complex statistics, since they are easily understood. In this paper, quantitative data analysis is used to analyze data particularly by summarizing the findings in terms of tables and graphs. The paper also employs trend analysis which is undertaken on the three KPIs for targets and achievements for the Ten (10) years. To add on this, correlation is also undertaken to find out if there is any relationship between access to safe water, customer satisfaction and the three indicators under study (budget expenditure, automation, employee satisfaction). Quantitative data analysis is used because of the numerical variable used, which allows the reporting of summary results in numerical terms that can be generalized to larger population. It also explores specific and clearly defined questions that examine 
INTERNATIONAL JOURNAL OF ACADEMIC RESEARCH IN BUSINESS AND SOCIAL SCIENCES Vol. 10, No. 11, 2020, E-ISSN: 2222-6990 @ 2020 HRMARS

the relationship between two events where the second event is a consequence of the first event (Kothari (2011).

The data from this paper is presented in form of tables and graphs which was used to demonstrate trend analysis and correlation. Quantitative Data was analyzed using Ms. Excel. Further still, tabulations and charts are also used to summarize and present the findings. Correlation coefficients are used to establish the relationships between and among the variables, the focus being the relationship between dependent variable and the independent variables for the study. Pearson's correlation coefficient, $r$, is used because data used is of interval level of measurement. In addition it is appropriately used as opposed to using factor analysis which requires larger data.

To find out the relationship between access to safe water $\left(Y_{1}\right)$ customer satisfaction $\left(Y_{2}\right)$ and the three variables under study (budget absorption $\left(X_{1}\right)$, service automation $\left(X_{2}\right)$, and employee satisfaction $\left(\mathrm{X}_{3}\right)$ ), the Pearson formula of correlation is used;

$$
r=\frac{\left.N \sum x y-\left[\sum x\right)\left(\sum y\right)\right]}{\sqrt{\left.\left.\left[N \sum x^{2}-\left(\sum x\right)^{2}\right)\right]\left[N \sum y^{2}-\left(\sum y\right)^{2}\right)\right]}}
$$

The analysed information is then used to come up with conclusions and key recommendations that could be used to improve service delivery.

\section{Results and Discussion Of Findings}

The section presents the results of the study based on the major research questions that guided the study. These include; how have budget expenditure, automation and employee satisfaction affected service delivery? (Access to safe and clean water and customer satisfaction)

\section{Key Performance Indicators (KPIs)} follows:

In this paper, the key indicators that were used for tracking performance were defined as

Table 1 Key Performance Indicators

\begin{tabular}{|c|c|c|}
\hline S/no & Indicator & Definition \\
\hline 1 & $\begin{array}{l}\text { Access to safe and clean } \\
\text { water }\end{array}$ & $\begin{array}{l}\text { Proportion (\%) of national population with access to safe and } \\
\text { clean water }\end{array}$ \\
\hline 2 & Customer satisfaction & $\begin{array}{l}\text { Refers to the utility derived by the customers of the product or } \\
\text { service. Computed as \%- composite score from the annual } \\
\text { independent customer satisfaction surveys }\end{array}$ \\
\hline \multirow[t]{2}{*}{3} & Budget Absorption level & Relationship between total expenditure and approved budget. \\
\hline & & Computed as BA $=\frac{\text { Total Budget Absorption }}{\text { Approved budget }}$ \\
\hline 4 & Service Automation & $\begin{array}{l}\text { Refers to the extent to which the Ministry keeps in pace with } \\
\text { developments in Information and Communication Technology } \\
\text { (ICT). The thrust of this indicator is on ICT development as a } \\
\text { package. Computed as automation level in percentage (\%) }\end{array}$ \\
\hline 5 & Employee Satisfaction & $\begin{array}{l}\text { Refers to the utility derived from a worker for the quality of } \\
\text { services he offers to the public. Measured in percentage (\%) }\end{array}$ \\
\hline
\end{tabular}


INTERNATIONAL JOURNAL OF ACADEMIC RESEARCH IN BUSINESS AND SOCIAL SCIENCES Vol. 10, No. 11, 2020, E-ISSN: 2222-6990 @ 2020 HRMARS

\section{Ministry's Performance}

\section{Access to Safe and Clean Water}

The Ministry is mandated to provide access to clean and safe water to the population. The table presents the targets and achievements over the FY period 2005/06 to 2014/15.

Table 2 Proportion (\%) of population with access to clean water

\begin{tabular}{lllllllllll}
\hline \multicolumn{7}{l}{ Proportion (\%) of Population with Access to safe and clean water- 2005/06-2014/15 } \\
\hline FY & $\mathbf{2 0 0 5 /}$ & $\mathbf{2 0 0 6 /}$ & $\mathbf{2 0 0 7 /}$ & $\mathbf{2 0 0 8 /}$ & $\mathbf{2 0 0 9 /}$ & $\mathbf{2 0 1 0 /}$ & $\mathbf{2 0 1 1 /}$ & $\mathbf{2 0 1 2 /}$ & $\mathbf{2 0 1 3 /}$ & $\mathbf{2 0 1 4 /}$ \\
& $\mathbf{0 6}$ & $\mathbf{0 7}$ & $\mathbf{0 8}$ & $\mathbf{0 9}$ & $\mathbf{1 0}$ & $\mathbf{1 1}$ & $\mathbf{1 2}$ & $\mathbf{1 3}$ & $\mathbf{1 4}$ & $\mathbf{1 5}$ \\
Target & 40 & 45 & 50 & 53 & 56 & 59 & 62 & 65 & 69 & 73 \\
$\begin{array}{l}\text { Achievem } \\
\text { ent }\end{array}$ & 39.04 & 36.95 & 47 & 46 & 48 & 52 & 53 & 54 & 53 & 55 \\
\hline
\end{tabular}

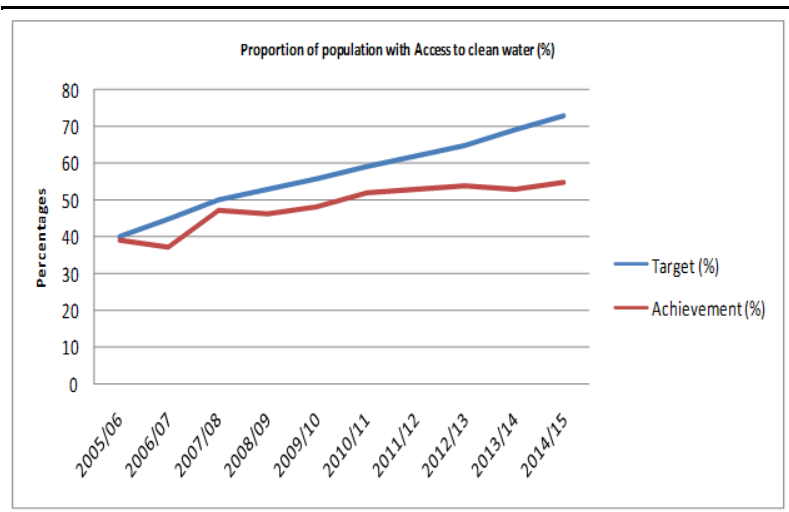

Source: IMPACT reports (various); Sector Investment Plan for the Water and Sanitation sector in Kenya 2009.

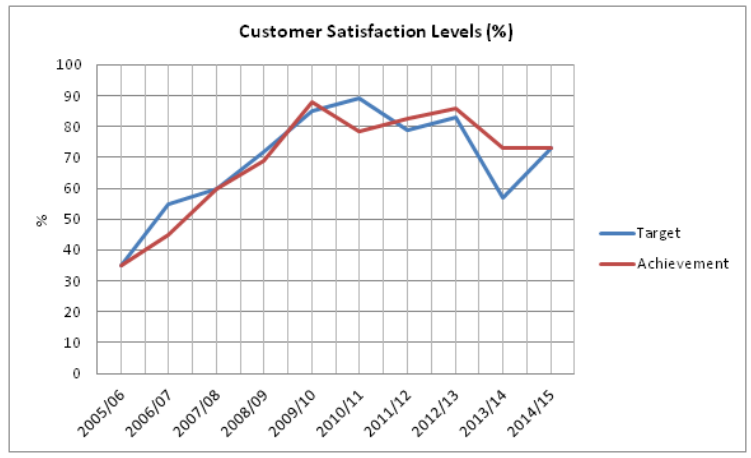

Figure 1: Proportion of population with access to clean water (\%)

As shown in figure 4.1, there has been progressive realization on access to clean water which has improved from 39\% in FY2005/06 to 55\% in FY2014/15. However, the targets were not realized.

\section{Customer Satisfaction level}

The Ministry is mandated to provide services to increase customer satisfaction levels. The table below presents the targets and achievements over the period FY2005/06 to FY2014/15 
INTERNATIONAL JOURNAL OF ACADEMIC RESEARCH IN BUSINESS AND SOCIAL SCIENCES Vol. 10, No. 11, 2020, E-ISSN: 2222-6990 @ 2020 HRMARS

Table 3: Customer Satisfaction level (\%)

\begin{tabular}{lllllllllll}
\hline \multicolumn{1}{l}{ Customer Satisfaction levels (\%) } & FY 2005/06-2014/15 & & & & \\
\hline FY & $\mathbf{2 0 0 5 /}$ & $\mathbf{2 0 0 6 /}$ & $\mathbf{2 0 0 7 /}$ & $\mathbf{2 0 0 8 /}$ & $\mathbf{2 0 0 9 /}$ & $\mathbf{2 0 1 0 /}$ & $\mathbf{2 0 1 1 /}$ & $\mathbf{2 0 1 2 /}$ & $\mathbf{2 0 1 3 /}$ & $\mathbf{2 0 1 4 /}$ \\
& $\mathbf{0 6}$ & $\mathbf{0 7}$ & $\mathbf{0 8}$ & $\mathbf{0 9}$ & $\mathbf{1 0}$ & $\mathbf{1 1}$ & $\mathbf{1 2}$ & $\mathbf{1 3}$ & $\mathbf{1 4}$ & $\mathbf{1 5}$ \\
Target & 35 & 55 & 60 & 72 & 85 & 89 & 79 & 83 & 56.7 & 73.1 \\
Achievemen & 35 & 45 & 60 & 69 & 88 & 78.45 & 82.4 & 86 & 73.1 & 73.1 \\
$t$
\end{tabular}

Source: MWI Performance Contract Progress reports (various 2005/06- 2014/15).

Figure 2: Customer Satisfaction level (\%)

As shown in figure 1, customer satisfaction levels have been improving overtime but dropped to $73 \%$ in FY2014/15 from 86\% in FY2012/13. The targets were surpassed over the period except for the FY2006/07, 2008/09 and 2010/11.

Findings According to the Research Questions How does Budget Absorption in Performance Contracting Affect Service Delivery?

The study sought to find out the trend on budget expenditure and how it affects service delivery using proxies of access to clean water and customer satisfaction. The findings of the trend and correlation are summarized in table 4.

Trend Analysis for Approved and Actual Budget Absorption on service delivery Table 4: Expenditure Review Ksh. Millions

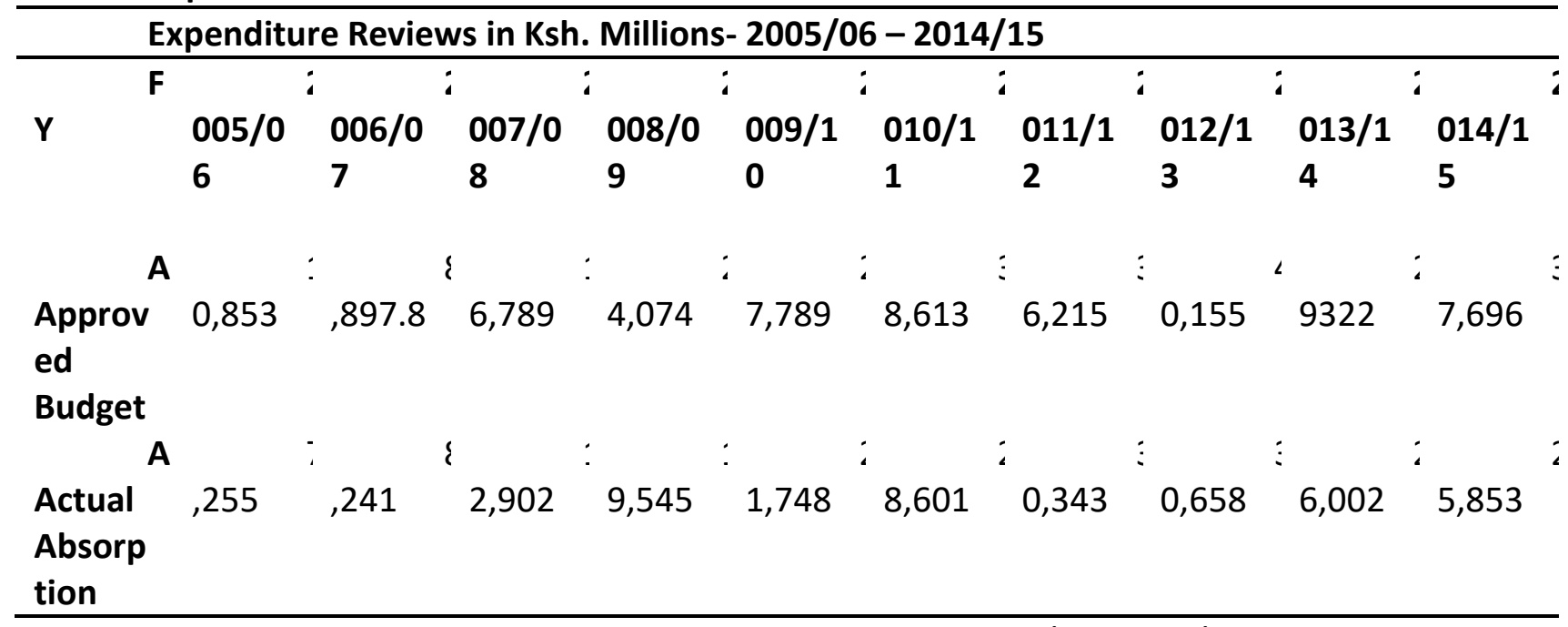

Source: MWI Performance Contract Progress reports (various 2005/06- 2014/15). 
INTERNATIONAL JOURNAL OF ACADEMIC RESEARCH IN BUSINESS AND SOCIAL SCIENCES Vol. 10, No. 11, 2020, E-ISSN: 2222-6990 @ 2020 HRMARS

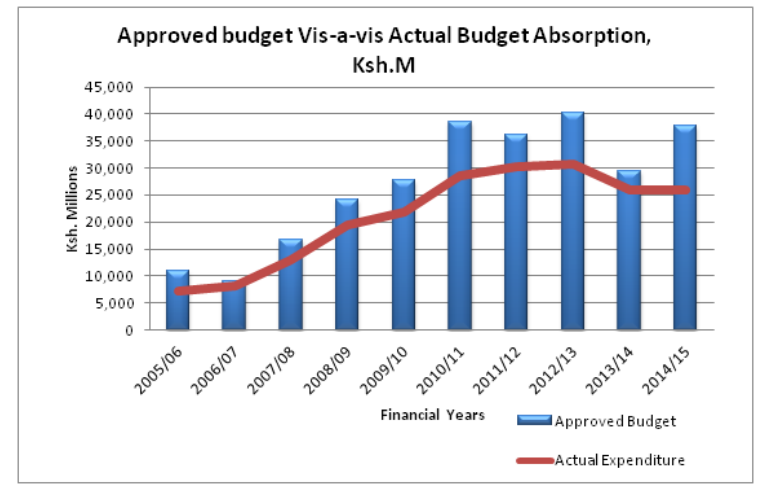

Figure 3: Budget Absorption review- Ksh.M

The approved budget for the Ministry had increased progressively over the period under review by 247\% from Ksh.10, 853M in FY2005/06 to Ksh. 37,696 M in FY2014/15. However, there was a major decrease in funding in FY2013/14. The actual absorption improved by 356\% from Ksh.7, $255 \mathrm{M}$ in FY2005/06 to Ksh. 37,696 M in FY2014/15.

\section{1) Trend Analysis for Actual Budget Absorption on customer satisfaction}

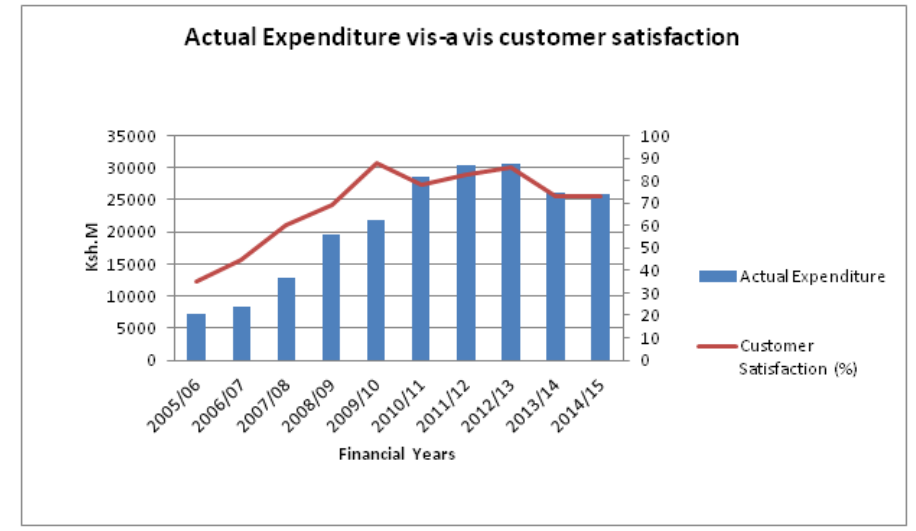

Figure 4: Actual Budget Absorption versus customer satisfaction

As depicted in Figure 4, there is improved customer satisfaction level as budget absorption increases. However, there was a decrease in customer satisfaction level in FY2013/14 when budget absorption decreased.

2) Trend Analysis for Actual budget absorption on access to clean water

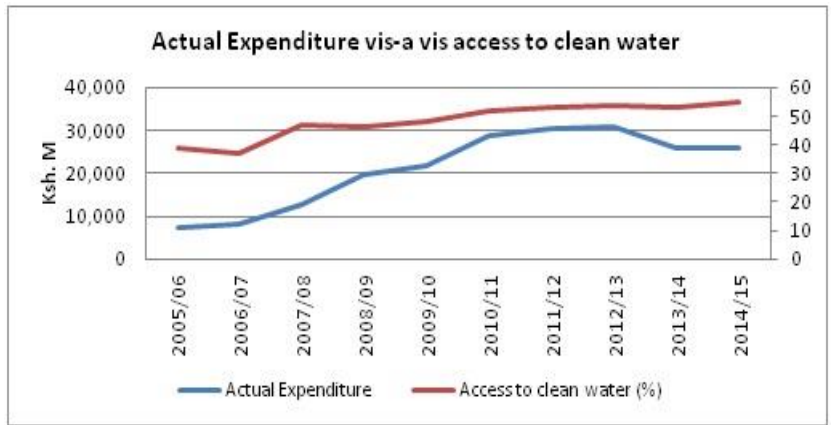

Figure 5: Actual Budget Absorption versus Access to clean water 
INTERNATIONAL JOURNAL OF ACADEMIC RESEARCH IN BUSINESS AND SOCIAL SCIENCES Vol. 10, No. 11, 2020, E-ISSN: 2222-6990 @ 2020 HRMARS

As depicted in Figure 5, there was improved access to clean water as budget absorption increased. However, there was a decrease in access to clean water in FY2013/14 when budget absorption decreased.

\section{Correlation between Actual Absorption and Service Delivery}

1) Correlation between Actual Absorption and Customer Satisfaction Table 5: Correlation between Budget Absorption and Customer Satisfaction

\begin{tabular}{lll}
\hline Variables & Access to Clean Water & Customer Satisfaction \\
\hline Budget Absorption & 0.9335 & $\mathbf{0 . 9 0 3 9}$ \\
Service Automation & -0.4065 & -0.2803 \\
Employee Satisfaction & 0.4523 & 0.3098 \\
\hline
\end{tabular}

$\mathrm{N}=10$

The he analysis suggests that there is a strong positive relationship of $90 \%$ on Budget Absorption and Customer Satisfaction. Thus as the Budget Absorption increases, Customer Satisfaction levels increases hence improved service delivery through implementation of performance contract in the Ministry.

2) Correlation between actual Budget Absorption and Access to Clean water Table 6: Correlation between budget absorption and access to clean water

\begin{tabular}{lll}
\hline Variables & Access to Clean Water & Customer Satisfaction \\
\hline Budget Absorption & $\mathbf{0 . 9 3 3 5}$ & 0.9039 \\
Service Automation & -0.4065 & -0.2803 \\
Employee Satisfaction & 0.4523 & 0.3098 \\
\hline
\end{tabular}

$\mathbf{N}=\mathbf{1 0}$

The analysis indicates that there is a strong positive relationship of 93\% between Budget Absorption and Access to clean water. This implies that increases in budget absorption lead to increased access to clean water thus improving service delivery through implementation of performance contract in the ministry.

What is the effect of Service Automation in performance contracting on service delivery? The study sought to determine the effect of service automation on service delivery. The analysis for the trend and correlation are shown below:

Trend analysis for automation levels

Table 7: Automation levels (\%)

\begin{tabular}{|c|c|c|c|c|c|c|c|c|c|c|}
\hline \multicolumn{11}{|c|}{ Automation kvels $(90)-2005 / 06-201415$} \\
\hline FY & 200506 & $2006 / 07$ & $2007 / 08$ & $2008 / 09$ & $2009 / 10$ & $2010 / 11$ & $2011 / 12$ & 201213 & $2013 / 14$ & 201415 \\
\hline Target & 60 & 80 & 50 & 60 & 55 & 60 & 55 & 65 & 35 & 58 \\
\hline Achierement & 60 & 75 & 50 & 51 & 52 & 55 & 62 & 65 & 35 & 57.6 \\
\hline
\end{tabular}

Source: MWI Performance Contract Progress reports (various 2005/06- 2014/15). 
INTERNATIONAL JOURNAL OF ACADEMIC RESEARCH IN BUSINESS AND SOCIAL SCIENCES Vol. 10, No. 11, 2020, E-ISSN: 2222-6990 @ 2020 HRMARS

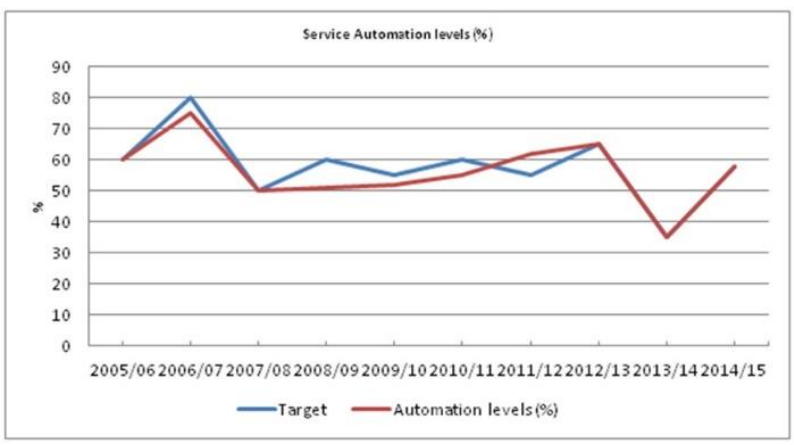

Figure 6: Service Automation levels (\%)

As shown in Figure 6, Service Automation levels had been increasing over the years though not achieving targets from FY2006/07 to FY2010/11. There was a drop in Service automation levels from $75 \%$ in FY2006/07 to 50\% in 2007/08, due to introduction of new guidelines on automation. A drop in automation levels was realized in FY2013/14 after creation of the new Ministry with an expanded mandate.

Trend analysis of Service Automation levels on service delivery

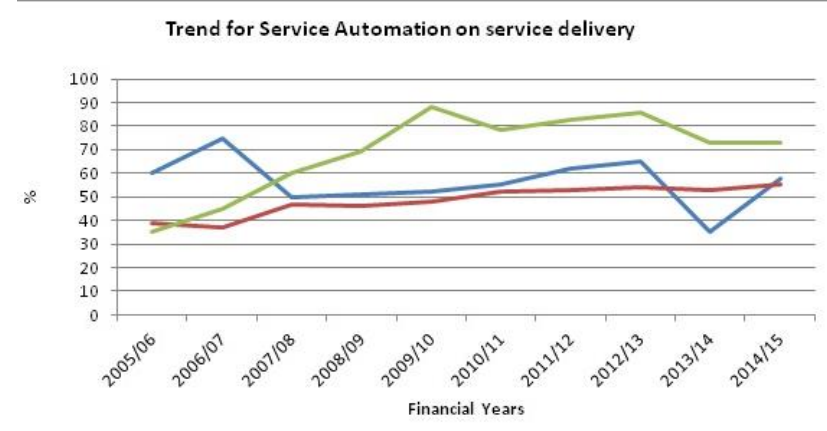

- Automation levels $(\%) \quad$ - Accessto clean water $(\%) \quad$ Customer Satisfaction $(\%)$

Figure 7: Trends for service Automation levels on service delivery

Figure 7 shows trends on service automation level to access to clean water and customer satisfaction. The study indicated that there is low relationship between service automation and customer satisfaction with access to clean water.

Correlation between Service automation levels and service delivery

1) Correlation between Service automation levels and Customer satisfaction

Table 8: Correlation between automation level and customer satisfaction

\begin{tabular}{lll}
\hline Variables & Access to Clean Water & Customer Satisfaction \\
\hline Budget Absorption & 0.9335 & 0.9039 \\
Service Automation & -0.4065 & $\mathbf{- 0 . 2 8 0 3}$ \\
Employee Satisfaction & 0.4523 & 0.3098 \\
\hline
\end{tabular}

$\mathrm{N}=10$ 
INTERNATIONAL JOURNAL OF ACADEMIC RESEARCH IN BUSINESS AND SOCIAL SCIENCES Vol. 10, No. 11, 2020, E-ISSN: 2222-6990 @ 2020 HRMARS

The analysis indicates that there is a low relationship of $28 \%$ between automation level and customer satisfaction. This implies that service automation level in the Ministry has minimal contribution to customer satisfaction hence service automation has little contribution to service delivery. These results agrees with a similar study by Mohammed (2014) in which he established $70 \%$ of librarians believed that automation had improved the library services while $85 \%$ users believed that an automated library system is better than the traditional manual system. However at the initial stages during orientation of the automation of the system to the users $60 \%$ did not view this automation as improving access to library services and hence it created user dissatisfaction. This could explain why in our study there seems to be dissatisfaction due to automation.

2) Correlation between service automation levels and access to clean water

Table 9: Correlation between service automation levels and access to clean water

\begin{tabular}{lll}
\hline Variables & $\begin{array}{l}\text { Access } \\
\text { Clean Water }\end{array}$ & $\begin{array}{l}\text { Customer } \\
\text { Satisfaction }\end{array}$ \\
\hline $\begin{array}{l}\text { Budget } \\
\text { Absorption }\end{array}$ & 0.9335 & 0.9039 \\
$\begin{array}{l}\text { Service } \\
\text { Automation }\end{array}$ & $\mathbf{- 0 . 4 0 6 5}$ & -0.2803 \\
$\begin{array}{l}\text { Employee } \\
\text { Satisfaction }\end{array}$ & 0.4523 & 0.3098 \\
\hline $\mathbf{N}=10$ & & \\
\hline
\end{tabular}

The analysis indicates that there is fairly low correlation of $41 \%$ between service automation level and access to clean water. The finding therefore implies that service automation level in the Ministry has less contribution to access to clean water hence not contributing much to the service delivery.

How does Employee satisfaction in performance contracting affect service delivery?

The study sought to determine the effect of employee satisfaction on service delivery. The analysis of the trend and correlation were summarized below:

1. Trend Analysis for Employee Satisfaction

Table 10: Trends on Employee Satisfaction levels (\%)

\begin{tabular}{|c|c|c|c|c|c|c|c|c|c|c|}
\hline \multicolumn{11}{|c|}{ Employee Satisfaction levels $(90)-200500$ - 201415 } \\
\hline FY & 200506 & 200607 & 2007108 & 200809 & $2009 / 10$ & $2010 / 11$ & $2011 / 12$ & 201213 & $2013 / 14$ & 201415 \\
\hline Target & 70 & 80 & 80 & 80 & 75 & 69 & 702 & 74.2 & 57 & 67 \\
\hline Achierement & 70 & 52 & 80 & 72 & 67.1 & 69.2 & 732 & 73.2 & 67 & 67 \\
\hline
\end{tabular}

Source: MWI Performance Contract Progress reports (various 2005/06- 2014/15). 
INTERNATIONAL JOURNAL OF ACADEMIC RESEARCH IN BUSINESS AND SOCIAL SCIENCES Vol. 10, No. 11, 2020, E-ISSN: 2222-6990 @ 2020 HRMARS

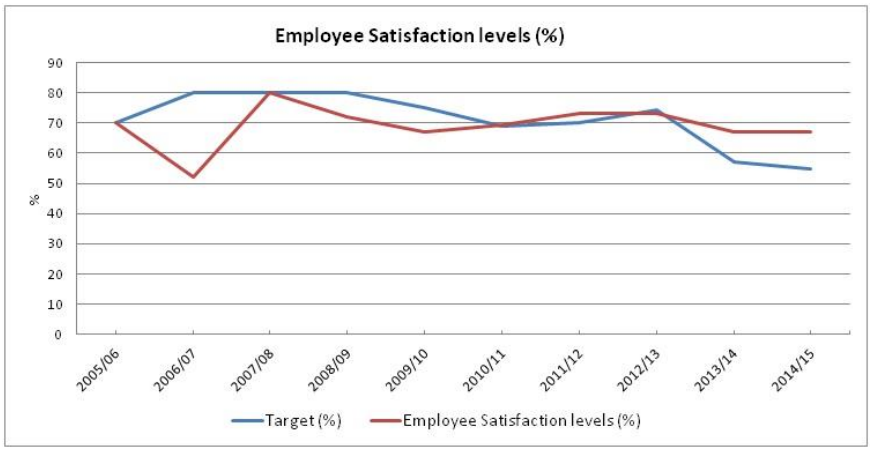

Figure 8: Employee Satisfaction levels (\%)

Figure 8 depicts improved employee satisfaction levels; however, there is a major drop in the levels from $70 \%$ in $\mathrm{FY} 2005 / 06$ to $52 \%$ in FY2006/07.

Trend Analysis of Employee Satisfaction on Service delivery

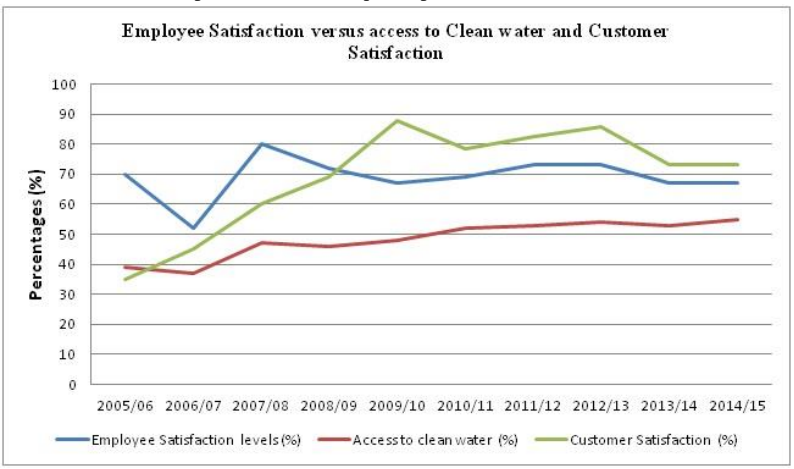

Figure 9: Employee Satisfaction versus Customer satisfaction and access to clean water

There is low relationship between the independent variable (employee satisfaction) and the dependent variables (customer satisfaction and access to clean water). Increase in employee satisfaction has a fair correspondence on increase on access to clean water.

Correlation between employee satisfaction and service delivery

Correlation between employee satisfaction and customer satisfaction.

Table 11: Correlation between employee satisfaction and customer satisfaction

\begin{tabular}{lll}
\hline Variables & $\begin{array}{l}\text { Access } \\
\text { Clean Water }\end{array}$ & $\begin{array}{l}\text { Customer } \\
\text { Satisfaction }\end{array}$ \\
\hline $\begin{array}{l}\text { Budget } \\
\text { Absorption }\end{array}$ & 0.9335 & 0.9039 \\
$\begin{array}{l}\text { Service } \\
\text { Automation } \\
\text { Employee }\end{array}$ & -0.4065 & -0.2803 \\
Satisfaction & 0.4523 & $\mathbf{0 . 3 0 9 8}$ \\
\hline $\mathrm{N}=10$ & &
\end{tabular}

$\mathrm{N}=10$ 
INTERNATIONAL JOURNAL OF ACADEMIC RESEARCH IN BUSINESS AND SOCIAL SCIENCES Vol. 10, No. 11, 2020, E-ISSN: 2222-6990 @ 2020 HRMARS

The analysis indicates that there is a low positive relationship of $31 \%$ between employee satisfaction and customer satisfaction. The finding indicates that there is a low contribution of employee satisfaction that leads to customer satisfaction in the ministry. The findings are corroborated by similar studies by Jeon and Choi (2012) on the how employee satisfaction affects customer satisfaction. Their findings indicated the relationship is dependent on dispositional variables such as self efficacy and cooperative orientation moderate the effect of this relationship. The low positive relationship in this case could indicate that there are other moderating factors that if well addressed could lead to a higher positive relationship between employee satisfaction and customer satisfaction.

Correlation between employee satisfaction and access to clean water.

Table 12: Correlation between employee satisfaction and access to clean water

\begin{tabular}{lll}
\hline Variables & $\begin{array}{l}\text { Access } \\
\text { Clean Water }\end{array}$ & $\begin{array}{l}\text { Customer } \\
\text { Satisfaction }\end{array}$ \\
\hline $\begin{array}{l}\text { Budget } \\
\text { Absorption }\end{array}$ & 0.9335 & 0.9039 \\
$\begin{array}{l}\text { Service } \\
\text { Automation }\end{array}$ & -0.4065 & -0.2803 \\
$\begin{array}{l}\text { Employee } \\
\text { Satisfaction }\end{array}$ & $\mathbf{0 . 4 5 2 3}$ & 0.3098 \\
\hline
\end{tabular}

$\mathrm{N}=10$

The analysis indicates that there is a fairly positive relationship of $45 \%$ between employee satisfaction and access to clean water. Thus the finding shows there is fair contribution of employee satisfaction on access to clean water hence improved service delivery in the ministry. The findings are also supported by similar studies by Jeon and Choi (2012) on the relationship between employee satisfaction and customer satisfaction. They established that employee satisfaction leads to customer satisfaction when dealing with direct service sector, but this diminishes as the level of indirect service provision increases. In this study, the provision of clean water is an indirect service through mechanization and other service processes and hence the relatively lower correlation between employee satisfaction and provision of clean water.

\section{Conclusion and Recommendations Conclusion}

The study sought to measure the effect of Key Performance Indicators in the Performance Contract on service delivery. The analysis indicated that there is a strong linear relationship of $90.4 \%$ between Budget Absorption, while there was a weak relationship of $28.03 \%$ for Service automation and $31 \%$ was the resultant correlation relationship between Employee satisfaction and the dependent variable Customer satisfaction. The analysis also indicates that there is a strong linear relationship of $93 \%$ between independent variables of Budget absorption, $40 \%$ Service automation and $45.2 \%$ Employee Satisfaction and dependent variable Access to clean water.

From these research findings, Budget absorption is critical in enhancing service delivery of the department. Research by Kobia and Mohammed (2011) corroborates these findings with their findings on how performance contracting was enhanced by statutory obligations including the absorption of budget. The utilization of allocated resources facilitates performance processes which 
INTERNATIONAL JOURNAL OF ACADEMIC RESEARCH IN BUSINESS AND SOCIAL SCIENCES Vol. 10, No. 11, 2020, E-ISSN: 2222-6990 @ 2020 HRMARS

greatly improve performance. The findings on the other hand suggest that employee satisfaction and Service Automation may enhance performance but are of less significance when dispensing services. This argument agrees with the findings of Njagi, (2011) in which the automation of services in tea picking in Kenya had a negative effect on overall delivery of the firm targets due to motivational factors. Automation should be employed to enhance processes and not necessarily to replace human services in labour intensive production activities. The nature of the service automation and the employee satisfaction initiatives being put in place by the Ministry need to be appropriate to have a significant effect on service delivery. Similarly employee satisfaction cannot be a direct contributor to service delivery if the necessary environment is not provided such as motivation to achieve higher targets.

\section{Recommendations}

Based on the research paper findings, the researcher makes the following recommendations:

1. Since budget absorption has a positive significant influence on service delivery, and hence the Ministry of Water and Irrigation should enhance sustainable budgetary increases, particularly in water infrastructure so as to continuously improve service delivery. This will help the department to fully utilize the allocated funds and therefore project completion rates will also be greatly enhanced.

2. On the weak relationship between automation and service delivery, the researchers recommend that other than for improving internal ICT infrastructure, the Ministry of Water and Irrigation should also improve on automation of its core public services (e-services) that will improve service delivery to the public. This will make it easy for customers to easily access the services from the department thereby greatly contributing towards the realization of performance targets.

3. The gap between employee satisfaction with the use of the PC overally and customer satisfaction is another surprise finding that requires a deeper understanding. There could be other underlying factors that require consideration and hence need for study. The authors therefore recommend that studies need to be carried out to establish the employee satisfaction initiatives and why they are not in tandem with service provision

4. Further studies should be undertaken for all the other key performance indicators in the performance contract to assess their relevance to service delivery. 
INTERNATIONAL JOURNAL OF ACADEMIC RESEARCH IN BUSINESS AND SOCIAL SCIENCES Vol. 10, No. 11, 2020, E-ISSN: 2222-6990 @ 2020 HRMARS

\section{References}

African Development Bank. (2012). Performance Contracting and Social Service delivery- lessons from Rwanda

Albeity, O. A. (2012). Effect of Performance Contracting on Service Delivery at Municipal Council of Mombasa, a Research Project, University of Nairobi. Unpublished research thesis.

Armstrong, M., \& Baron, A. (2004). Managing performance: performance management in action. London: Chartered Institute of Personnel and Development.

Bouckaert, E. (2009). Public Sector Performance Contracting in Belgium and Flanders, OECD. London: Cambridge University Press.

Ceasar, N. (2014). Assessment Of Performance Contracting In Public Teachers' Training Colleges In Kenya: A Case Of Thogoto Teachers Training College. Unpublished research thesis.

Chittoo, H., Ramphul, N., and Nowbutsing, B. (2009). Culture Mandala: Bulletin of the Centre for East-West Cultural \& Economic Studies, Vol. 8, Issue 2, December 2009, pp.30-51

Gakure, R. W., Muriu, S. M., and Orwa, G. (2013). Role of Performance Contracting in Enhancing Effectiveness of Performance in the Civil Service in Kenya, State Department of Infrastructure Journal of Business and Management Volume14, Issue 6, pg 73-82

Gruening, G. (2001). Origin and theoretical basis of New Public Management. International Public Management Journal 4 (2001) 1-25.

Kobia, M., Mohammed, N. (2006), The Kenyan Experience With Performance Contracting, African Association For Public Administration And Management, 8th AAPAM Annual Roundtable Conference, Arusha, Tanzania.

Kariuki, M. M., \& Kasomi, F. M. (2011). The perception of Kenyan Citizens on improvement of public service delivery since the implementation of performance contracts in Kenya. DBA African Management Review, 1(1).

Kothari, C. R.(2011). Research methodology. Methods and techniques. New Delhi:L New age international Publishers.

Obong'o, S. O. (2000) Implementation of Performance Contracting in Kenya. International Public Management Review. Electronic Journal at http://www.ipmr.net.Vol 10.issue2.2009

Larbi, A. (2000). Performance Contracting: Experiences and Lessons from Ghana. Accra: Macmillan.

Larbi, G. (2010). Performance contracting in practice: Experience and lessons learnt from the water sector in Ghana. Public Management Review. 3:3, pg 305-324, D01: 10.

1080/14616670110044018 http://www.tandfonline.com/loi/rpxm20

Letangule, S., and Letting, N. (2012). Effect of performance contract on organizational performance; The case study of Kenya's Ministry of Education. International Journal of Management and Business Studies, Issue No. 3.

David, Y., Miller, W. D. (2007) A critical theory of new public management

Mugenda, O. M., \& Mugenda, A. G. (2012). Research Methods Quantitative and Qualitative Approches. Nairobi: ACTS Press.

Muthaura, F. K. (2010). The role of Kenya public service in a changing global environment: opportunities and challenges-what is working and what is not? Paper presented at the KAPAM annual dinner, Hilton Hotel, Nairobi.

Nganyi, J. E., Shigogodi, J. M., Owano, A. (2014). The Effectiveness of Performance Contracting in Service Delivery in Public Universities in Kenya. International Journal of Academic Research in Business and Social Sciences October 2014, Vol. 4, No. 10,pg 413-441. 
INTERNATIONAL JOURNAL OF ACADEMIC RESEARCH IN BUSINESS AND SOCIAL SCIENCES Vol. 10, No. 11, 2020, E-ISSN: 2222-6990 @ 2020 HRMARS

Njagi, A. S. N. (2011). The Impact of Automation On Operational Performance: A Study Of Kenya Tea Development Agency Managed Factories.

Oso,W. Y., \& Onen, D. (2011). A general Guide to writing Research Proposal and Report; Handbook for Beginning Researchers, Nairobi: Jomo Kenyatta Foundation.

Orodho, A. J., \& Kombo, D. K. (2002). Research Methods, Masola Publishers, Nairobi.

Republic of Kenya. (2007). Kenya Vision 2030, Ministry of Planning and National Development. Retrieved April 3, 2017, from: http://www.opendata.go.ke

Republic of Kenya. (2012). Public Procurement Oversight Authority Report, The National Treasury. Retrieved May 52017 from http://www.opendata.go.ke

Republic of Kenya. (2012). Kenya Bureau of Statistics. Kenya facts 2012. Retrieved May 1, 2017, from knbs.or.ke: http://knbs.or.ke/downloads/pdf/kenyafacts2012.pdf

Rhyne, E. (2001). Mainstreaming Microfinance, How lending to the poor began, grew and came of age in Bolivia, West Hartford, Kumarian Press.

Sifuna, O. N. (2012). Perceived effect of performance contracting on service delivery at Jomo Kenyatta University of Agriculture and Technology, a Research Project, University of Nairobi.

Stevenson, W. J. (2007): Operations Management, International Student $9^{\text {th }}$ Edition with Global headings, Edition, McGraw-Hill Irwin.

Trivedi, P. (2000). How to evaluate performance of Government agency: A manual for practitioner World Bank.

Trivedi, P. (2003). Performance Agreement in US Government: Lessons for Developing Countries Economic and Political weekly Vol. 38, No.46, Pg. 4859-4864.

Petri Uusikyla and Petri Virtanen (2012). Public Sector Performance Contracting In Finland, Public Management Department, Finnish Ministry of Finance

Piriyathanalai W. and Muenjohn N, Is there a link between Employee satisfaction and service quality World Journal of Management Vol. 4. No. 1. March 2012 Pp. 82 - 92 